\title{
Enzymatic activity in the shrimp Penaeus vannamei fed at different feeding frequencies
}

\author{
Luis Daniel García-Rodríguez ${ }^{1} \mathbb{D}$, Juan Carlos Sainz Hernández ${ }^{1} \stackrel{\mathbb{D}}{ }$, Jazmín Asusena Aguiñaga-Cruz $^{1} \mid$ \\ Cinthya Guadalupe Juárez Acosta ${ }^{1}\left(\mathbb{D}\right.$, Apolinar Santamaría-Miranda ${ }^{1} \mathbb{D}$ \& Juan Pablo Apun-Molina ${ }^{1}$ \\ ${ }^{1}$ Instituto Politécnico Nacional, CIIDIR Sinaloa, Guasave, Sinaloa, Mexico \\ Acuícola Cuate Machado, Salvador Alvarado, Sinaloa, México \\ Corresponding author: Juan Pablo Apun-Molina (japun@ipn.mx)
}

\begin{abstract}
Correct management of the feeding regime in shrimp aquaculture has been beneficial. Still, when looking for improvement in shrimp performance, the results have been contradictory, and the limits between better growth and independent growth as a function of the feeding regime are not clear. In this study, trypsin and $\alpha$-amylase activity, as well as an interpretation of the energy utilized for enzyme production, were evaluated in shrimp weighing $1 \mathrm{~g}$. Four feeding groups were set to feed one, two, four, or eight times per day over a month, after which trypsin and $\alpha$-amylase activities were evaluated during $29 \mathrm{~h}$. Results indicated that the group fed once per day ingested $90 \%$ of the feed, whereas the other groups ingested $100 \%$. The $\alpha$-amylase was not consumed during the daytime in all groups, unlike trypsin. Total trypsin activity was not significantly different between feeding groups, but $\alpha$-amylase was significantly different. Shrimp fed eight times had an elevated $\alpha$ amylase activity level that was 2.6 times greater than those fed only once, and 0.8 and 0.5 times greater than those fed four and twice per day, respectively. Feeding more frequently generates a higher use of energy that may or may not be reflected in growth but could be essential for all the energy-dependent metabolic processes required by shrimp.
\end{abstract}

Keywords: Penaeus vannamei; feeding frequency; trypsin activity; $\alpha$-amylase activity; aquaculture

\section{INTRODUCTION}

One of the approaches for optimizing feeding in shrimp ponds involves the feeding frequency and the circadian rhythm of the animals' digestive enzyme activity. Studies on feeding frequency and its effects on shrimp growth are conflicting. Some works showed a positive effect on shrimp growth when feeding frequency increased (Sedgwick 1979, Robertson et al. 1993, Tacon et al. 2002); however, others found no direct relationship between these two factors (Velasco et al. 1999, Smith et al. 2002, Carvalho \& Nunes 2006). It is known that shrimp can vary their diet from vegetal to animal sources and utilize bacteria and algae of the water as food. Information on the diet, feeding habits, and ecological niche of the shrimp (Rodríguez-Viera et al. 2014) are necessary to understand the strategy of obtaining nutrients.

Carbohydrate hydrolysis has been studied in crustaceans to help understand what role it plays in nutrition.
Studies on the performance of $\alpha$-amylase regarding age and as a function of ingested feed-in semi-intensive aquaculture revealed that $\alpha$-amylase activity in Penaeus vannamei weighing $2 \mathrm{~g}$ was significantly lower compared with larger organisms. Simultaneously, smaller shrimp were more dependent on protein, whereas $P$. vanname $i$ decreases the ingestion of protein but increases carbohydrates' intake during growth (Gamboa-Delgado et al. 2003). An increase in $\alpha$ amylase activity with age is related to the rise of $\alpha$ amylase isoforms (from 7 to 10) revealed by sodium dodecyl sulphate-polyacrylamide gel electrophoresis (SDS-PAGE) (Castro et al. 2012). Trypsin isoform patterns of two or three remain during all ages of $P$. vannamei (Sainz-Hernández et al. 2005, AguiñagaCruz et al. 2017).

Different factors have been observed to influence $\alpha$ amylase and trypsin activity, like the molt cycle (Gaxiola et al. 2005) or whether the organisms are grown in aquaculture systems versus in nature (Castro

Corresponding editor: Sandra Bravo 
et al. 2012); total amylolytic activity in farmed shrimp was three times as high as that of wild shrimp. According to these works, this phenomenon occurs because the commercial feed components contain many carbohydrates. They postulated that $\alpha$-amylase activity depends on the species' natural diet, with herbivores and omnivores exhibiting significantly higher activity than carnivores (Johnston \& Freeman 2005, Simon 2009). In fish, production of $\alpha$-amylase is neither fed dependent nor of reflex origin (Hofer et al. 1982). Soares-Pontes et al. (2006) and Santos et al. (2016) described $P$. vannamei behavior during the day and at night and concluded that swimming occurred predominantly at night. They proposed that inactive shrimp during the daytime use limited stored energy and, therefore, food is transformed into biomass.

Trypsin found in $P$. vannamei is a polymorphic molecule composed of three isotrypsins synthesized as a zymogene (Klein et al. 1998, Sainz-Hernández et al. 2004b). There have been several studies on the trypsin activity of $P$. vannamei in which the organism was fed different diets and at different ages and physiological states. Trypsin's nucleotide sequence is known (Klein et al. 1996), as well as its genomic arrangement (Klein et al. 1998), its modulation (Sainz-Hernández et al. 2005, Aguiñaga-Cruz et al. 2019), and its biochemical characterization (Sainz-Hernández et al. 2004a). Trypsin activity dominates in penaeid shrimp larvae and is altered when the organisms change from herbivorous to carnivorous (Kumlu \& Jones 1995, Hernandez-Cortes et al. 2017). P. vannamei undergoes this critical change in trypsin activity and becomes carnivorous during an earlier developmental stage than other penaeids (Puello-Cruz et al. 2002).

The selection of phytoplankton as a primary source of diet by small larvae of $P$. vannamei (Le Vay et al. 2001) results in high trypsin activity and low $\alpha$-amylase activity related to the low protein and high carbohydrate content in phytoplankton (Harris et al. 1986, Harms et al. 1991). At the protozoea 2 (PZ2) stage, $P$. vanname $i$ changes from its phytophagous state to being carnivorous and starts feeding on zooplankton. At this point, its trypsin activity decreases, and its $\alpha$ amylase activity increases because zooplankton contains a pool of readily digestible protein and low carbohydrate content (Hernandez-Cortes et al. 2017). However, changes in the protease and $\alpha$-amylase activity rate during ontogeny are not directly associated with diet alone and appear to be genetically controlled (Lovett \& Felder 1990, Hernandez-Cortes et al. 2017). Due to the range of digestive enzymes and their activity levels, they appear to define the feeding strategy, and the type of prey consumed and are correlated with the development of the secretory digestive gland (DG) tissue (Lumasag et al. 2007). Dietary plant protein results in higher trypsin activity than dietary animal protein (Le Moullac \& Van Wormhoudt 1994, Le Moullac et al. 1997).

Trypsin activity has been proposed to be an excellent biochemical marker of digestive system status because proteases are synthesized as inactive precursors or zymogens (Sellos \& Van Wormhoudt 1992). In several studies, trypsin activity has been observed to increase before ingestion in $P$. vannamei (Hernandez-Cortes et al. 1999, Sainz-Hernández et al. 2005, Santos et al. 2016) and Litopenaeus schmitti (Díaz-Granda 1997), and to decrease after ingestion.

From the enzymatic point of view, the immediate research goals were to describe how the kinetics of enzymatic activity concentration (EAC) decrease or increase with different feeding rates and interpret how the energy is used to catalysis protein and carbohydrates in the $P$. vanname $i$ shrimp.

\section{MATERIALS AND METHODS}

\section{Experimental design}

The Penaeus vannamei shrimp were obtained from a postlarvae production laboratory in Sinaloa, Mexico, and cultured in the farm "Acuícola Cuate Machado", North-Guasave, Sinaloa, Mexico. The shrimp were cultured indoors in a $100 \mathrm{~m}^{3}$ container equipped with water filters $(10 \mu \mathrm{m})$ and continuous flow. The air was supplied with a one HP blower and diffused by air tubes; a greenhouse controlled the temperature at $28 \pm$ $2^{\circ} \mathrm{C}$, and shrimp were fed $10 \%$ of their biomass with Azteca shrimp feed ${ }^{\circledR}$ (35\% protein, $6 \%$ fat, $5 \%$ crude fiber, $10 \%$ moisture, $10 \%$ ash, and 34\% NFE) twice a day, at 8:00 and 20:00 $\mathrm{h}$.

When the average shrimp weight was $1 \mathrm{~g}$, the organisms were transferred to 12 containers of $78 \mathrm{~m}^{3}$ equipped with water filters $(10 \mu \mathrm{m})$ and continuous water flow. Shrimp were arranged for a completely randomized design as follows. Four groups were stocked at the same shrimp density (320 ind $\left.\mathrm{m}^{-3}\right)$, a total of 25,000 individuals per tank. Four different feeding regimes were set in triplicate: group $\mathrm{A}$ was fed once during the day; group B, two times; group $\mathrm{C}$, four times; and group D, eight times, as indicated in Figures 1 and 2. At the beginning of the experiment, the feeding groups were fed at $10 \%$ of their biomass per day to finish with $5 \%$ in different fractions for a month.

\section{Biological performance}

Weekly growth was monitored, and the biomass (\%) was adjusted to feed. The feed was applied in trays, and the amount of ingestion was recorded. The survival $=$ 


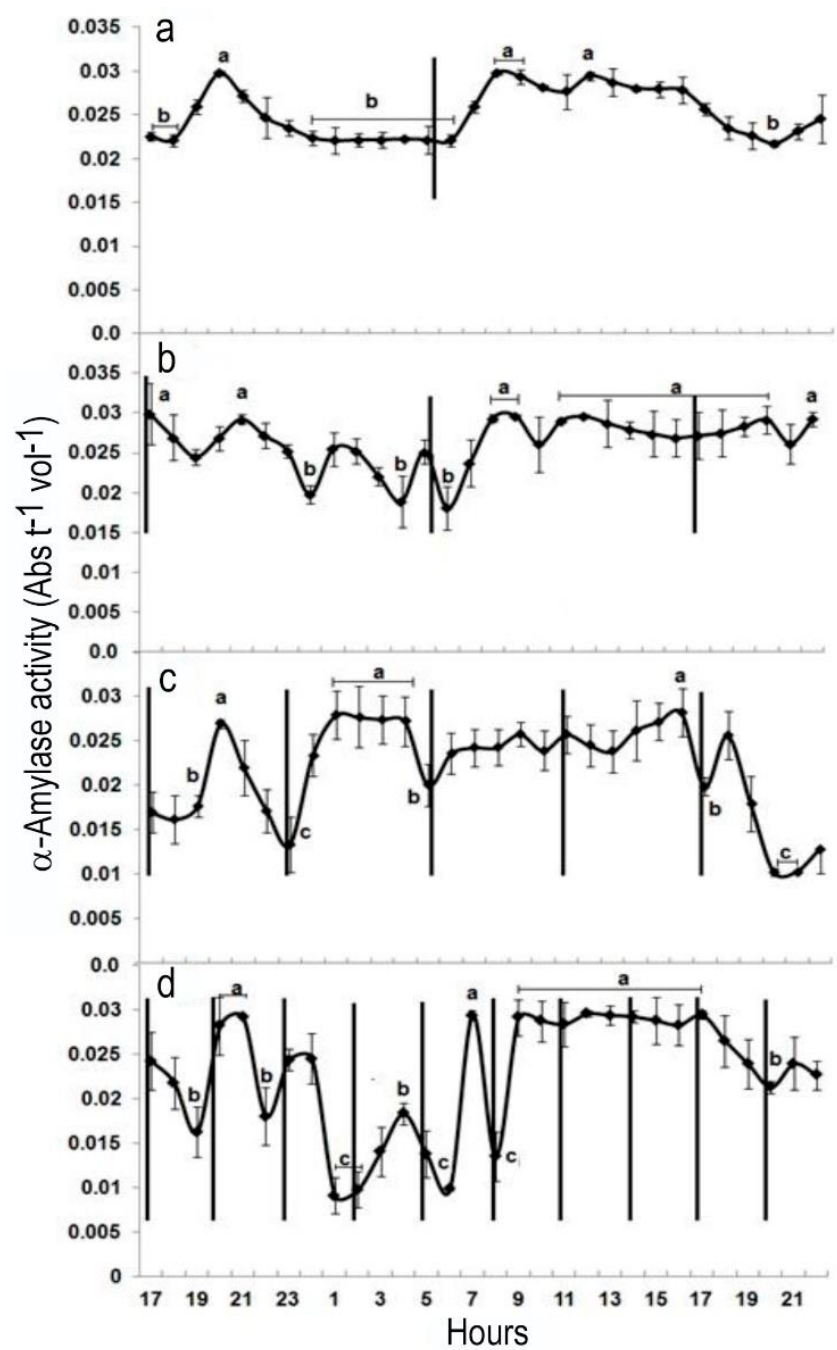

Figure 1. Effect of different feeding rates. a) Group A, feeding once: $24 \mathrm{~h}, \mathrm{~b}$ ) group B, two times: $12 \mathrm{~h}$, c) group C, three times: $6 \mathrm{~h}$, and d) group $\mathrm{D}$, eight times: $3 \mathrm{~h}$, on $\alpha$-amylase activity in the digestive glands of shrimp sampled during a feeding cycle. Vertical black lines indicate the feeding hour. Different lowercase letters indicate statistical significance $(\alpha=0.05 ; \mathrm{n}$ $=5$ ).

final number of shrimp - initial number of shrimp $\times 100$. Feed conversion ratio $(\mathrm{FCR})=\mathrm{F} /(\mathrm{Wf}-\mathrm{W} 0)$, where $\mathrm{F}$ is the weight of feed supplied to the shrimp during the assay, Wf: final weight, and W0: initial weight (ZiaeiNejad et al. 2006).

\section{Sample preparation}

After one month, samples of five shrimp in molting stage $\mathrm{C}$ were collected every hour per treatment and replicated over 29 h, as shown in Figure 1. Shrimp were euthanized by freezing, and then the DG was extracted and collected in $1.7 \mathrm{~mL}$ Eppendorf tubes and kept at $-70^{\circ} \mathrm{C}$. Each DG was homogenized (1:2) in distilled water in a Waring ${ }^{\circledR}$ blender. The homogenate was centrifuged three times for $30 \mathrm{~min}$ at $10,000 \mathrm{~g}$, and the aqueous extract was separated from the lipids and the sediment.

\section{Trypsin and $\alpha$-amylase activity assays}

Trypsin activity was quantified individually per shrimp, using $1 \mathrm{mM}$ benzoyl-arginine p-nitroaniline (BAPNA) in $20 \mathrm{mM}$ TRIS- $\mathrm{HCl}$ and $20 \mathrm{mM} \mathrm{CaCl}_{2}$, with a $\mathrm{pH}$ of 7.5 as the substrate (Erlanger et al. 1961). The amount of p-nitroaniline liberated from BAPNA at $35^{\circ} \mathrm{C}$ was calculated by increasing absorbance at $410 \mathrm{~nm}$ (extinction coefficient $=8800 \mathrm{M}^{-1} \mathrm{~cm}^{-1}$ ). One enzyme unit was defined as the amount of enzyme that hydrolyzes $1 \mathrm{mM}$ BAPNA per minute under the conditions described above. Total activity was expressed as enzyme units per volume of sample or EAC. 


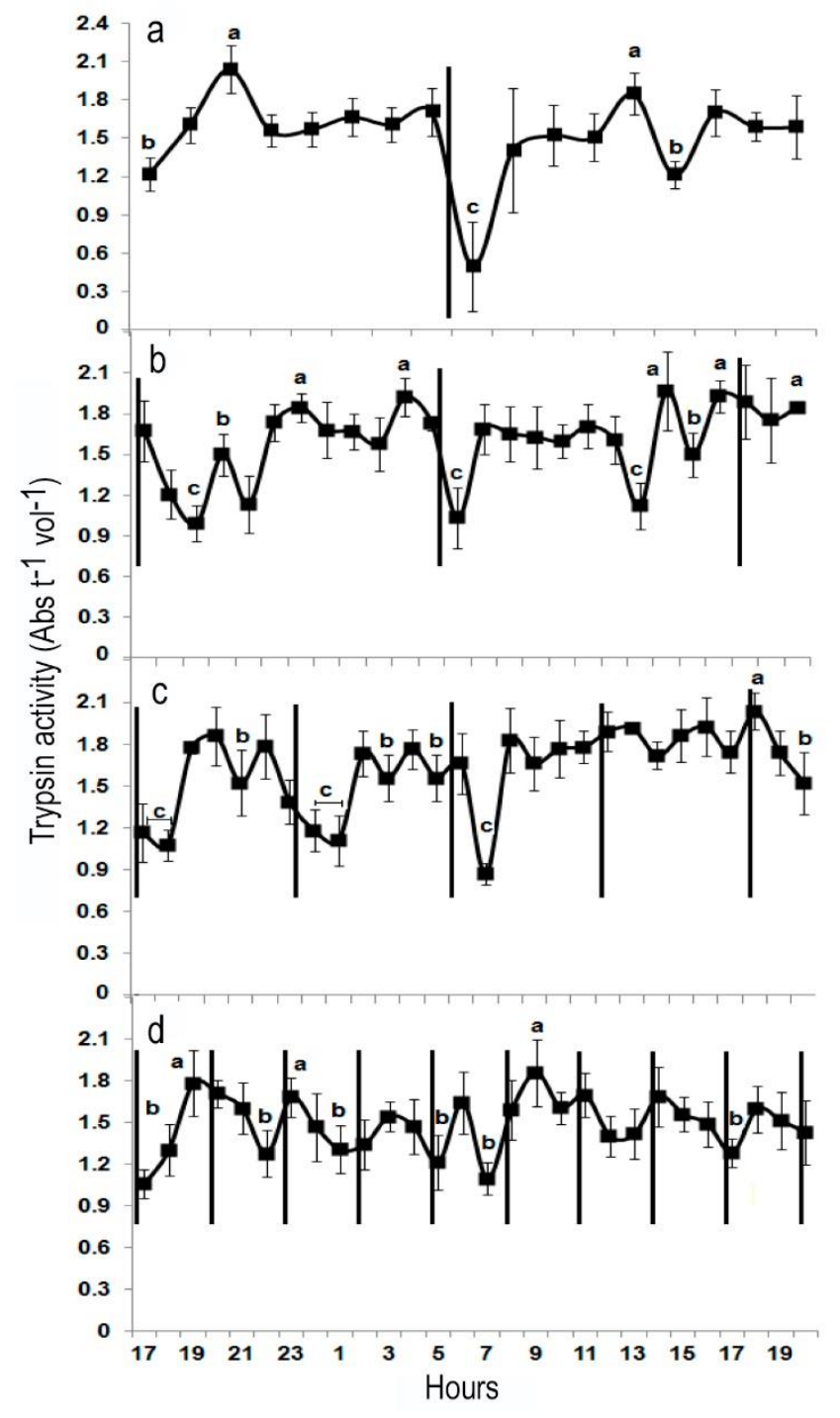

Figure 2. Effect of different feeding rates. a) Group A, feeding once: $24 \mathrm{~h}$, b) group B, two times: $12 \mathrm{~h}$, c) group C, three times: $6 \mathrm{~h}$, and d) group D, eight times: $3 \mathrm{~h}$, on trypsin activity the digestive glands of shrimp sampled during a feeding cycle. Vertical black lines indicate the feeding hour. Different lowercase letters indicate statistical significance $(\alpha=0.05 ; \mathrm{n}$ $=5$ ).

The $\alpha$-amylase activity was evaluated individually per sample, utilizing $50 \mu \mathrm{L}$ of crude enzyme extract that was incubated for $15 \mathrm{~min}$ at $30^{\circ} \mathrm{C}$ with $650 \mu \mathrm{L}$ of sodium citrate $(50 \mathrm{mM} ; \mathrm{pH} 5.0)$ containing $10 \mathrm{mM}$ $\mathrm{NaCl}, 20 \mathrm{mM} \mathrm{CaCl}$, and $500 \mu \mathrm{L}$ of a solution of $0.125 \%$ soluble starch in $50 \mathrm{mM}$ sodium citrate with a $\mathrm{pH}$ of 5.0. The reaction was stopped by the addition of $5.0 \mathrm{~mL}$ of iodine/iodide $\left(0.5 \% \mathrm{I}^{2}\right.$ and $\left.5 \% \mathrm{KI}\right)$. The absorbance of the blue color was determined at $580 \mathrm{~nm}$. Total activity was expressed as micromoles maltose enzyme delivered per minute, per volume of sample or EAC.

\section{Estimation of relative energy use}

Relative energy use was calculated about the EAC. Although it was not possible to quantify the actual consumption and the EAC increase, the data were analyzed to describe the relationship between the total elevations and decreases of EAC per feeding regime, with the following equation: $\sum \mathrm{El} / \sum \mathrm{De}=\mathrm{d} \mathrm{EAC}$. El: EAC elevations, De: EAC decreases, o EAC: EAC balance. Relative percent of activity was calculated considering the highest total activity elevation as of $100 \%$. Relative energy use estimate for EAC was calculated considering that in a system similar to that of 
the DG of P. vannamei, more activity requires more conversion of zymogen to the active enzyme and more transcription and translation of enzymes to cover the enzymatic activity demand. For the enzyme translation, four to six molecules of ATP are needed per peptide. Thus, the amount of EAC is proportional to the ATP consumed to translate the enzymes.

\section{Statistical analysis}

A sign test evaluated differences in activity among the different sampled hours of each feeding regime for dependent samples and a posteriori Wilcoxon matched pairs test. The level of significance was set at 0.05. To evaluate the significance among treatments on the variables: survival, final weight, weekly growth, feed intake, and feed conversion rate, a Kruskal-Wallis test was carried out.

\section{RESULTS}

\section{Biological performance}

Survival, final weight, weekly growth, feed intake, and feed conversion rate are depicted in Table 1. No significant difference $(P>0.05)$ was detected among treatments in any variable.

\section{Enzymatic activity concentration at different feeding frequencies}

Trypsin and $\alpha$-amylase activities concentration during a diurnal cycle

Feed intakes were $100 \%$ for groups B, C, and D, and $90 \%$ for group A. The five shrimp collected every hour per group were processed to determine the kinetics of the trypsin and $\alpha$-amylase activities during a diurnal cycle. During the night hours, more fluctuations in $\alpha$ amylase EAC were registered in the regimes with higher numbers of feedings, and a tendency to be stabilized at maximum activity during the day was found with all regimes (Fig. 1). The maximum $\alpha$ amylase activity was approximately 0.03 units in all regimes, but the minimum was lower when the feed was offered more frequently (Table 2). Total elevation in $\alpha$-amylase activity was high when feeding eight times per day and was significantly lower $(P<0.05)$ when feeding frequency decreased.

Fluctuations in $\alpha$-amylase activity were observed in all feeding groups. Group A, which was fed once during the day, showed the lowest fluctuations, followed by groups B and C; group D showed the most fluctuations in $\alpha$-amylase activity. Not all $\alpha$-amylase activity fluctuations were statistically significant. Group A showed two significant elevations and decreases. Group B one significant elevation and one reduction.
Group C, three significant elevations and four decreases, and group D, with its higher fluctuation, had four significant elevations and five decreases (Fig. 1).

Similar significant differences were detected among the four groups in the total elevation or decrease of $\alpha$ amylase EAC. Group A showed a significantly lower $\alpha$-amylase activity elevation and reduction than groups B, C, and D. No significant differences were detected between groups B and C. Group D was found to have a significantly higher total elevation decrease in $\alpha$ amylase activity than all other groups. The $\alpha$-amylase activity balance was approximately 1 .

Fluctuations in trypsin activity were observed in all feeding groups and reached a maximum during fasting periods and decreased to a minimum after feeding (Fig. 2, Table 2). More fluctuations were registered when increasing the feeding regime: group A, which had only one feeding during the day, showed the lowest fluctuations, followed by groups $\mathrm{B}$ and $\mathrm{C}$, whereas group D had the most fluctuations in trypsin activity. Not all trypsin activity fluctuations were statistically significant. Group A showed two significant elevations and decreases; group B five significant elevations and four decreases; group $C$ three significant elevations and decreases; group D, with its higher fluctuations, had three significant elevations and decreases (Fig. 2). There was no significant difference among the four groups in the total elevation or decrease in trypsin activity, and similar results occurred with the trypsin activity balance (Table 2). The decrease of trypsin activity was associated with feeding time in all groups, and stability in trypsin activity was observed in groups $\mathrm{B}$ and $\mathrm{C}$ during the morning after 07:00 $\mathrm{h}$.

Maximum trypsin activity was approximately 2.0 units when feeding one, two, or four times daily and decreased to 1.8 units when the feed was offered eight times per day. Minimum trypsin activity ( 0.5 units) was registered in the regime with only one intake, and 0.9 units of minimum activity were found for the other regimes (Table 2). Total elevation and an overall decrease of trypsin activity during the analyzed period showed no significant differences among the groups.

\section{DISCUSSION}

Shrimp (Penaeus vannamei), recently brought from the field and fed ad libitum in tanks had a natural cycle of trypsin activity that coincided with the maximum physical activity period after dusk. Although several small trypsin activity peaks were observed, shrimp appeared to starve during the day. This observation suggests an internal modulation of the digestive system in a $24 \mathrm{~h}$ cycle in nature (Hernandez-Cortes et al. 1999). 
Table 1. Biological performance of Penaeus vannamei subjected to four different feeding rates. Group A: feeding once per day, group B: two times, group C: four times, and group D: eight times $(\alpha=0.05)$.

\begin{tabular}{lccccc}
\hline $\begin{array}{l}\text { Feeding } \\
\text { group }\end{array}$ & $\begin{array}{c}\text { Survival } \\
(\%)\end{array}$ & $\begin{array}{c}\text { Final } \\
\text { weight }(\mathrm{g})\end{array}$ & $\begin{array}{c}\text { Weekly } \\
\text { growth }(\mathrm{g})\end{array}$ & $\begin{array}{c}\text { Feed intake } \\
(\%)\end{array}$ & $\begin{array}{c}\text { Feed conversion } \\
\text { rate }\end{array}$ \\
\hline A & $64.44 \pm 13.79$ & $4.605 \pm 0.268$ & $0.721 \pm 0.033$ & $90 \pm 2$ & $1.309 \pm 0.195$ \\
B & $66.89 \pm 5.64$ & $4.800 \pm 0.156$ & $0.760 \pm 0.020$ & 100 & $1.224 \pm 0.060$ \\
C & $64.22 \pm 8.91$ & $4.890 \pm 0.237$ & $0.778 \pm 0.029$ & 100 & $1.307 \pm 0.215$ \\
D & $69.00 \pm 10.74$ & $4.795 \pm 0.571$ & $0.759 \pm 0.065$ & 100 & $1.183 \pm 0.308$ \\
\hline
\end{tabular}

Table 2. The activity of trypsin and $\alpha$-amylase in the digestive gland of Penaeus vannamei subjected to four different feeding rates. Group A: feeding once per day, group B: two times, group C: four times, and group D: eight times. Different letters in the same columns indicate a statistical significance $(\alpha=0.05)$. EAC: enzymatic activity concentration.

\begin{tabular}{lcccccc}
\hline & $\begin{array}{c}\text { Feeding } \\
\text { group }\end{array}$ & $\begin{array}{c}\text { Range } \\
\text { of EAC }\end{array}$ & $\begin{array}{c}\text { Total EAC } \\
\text { elevation }\end{array}$ & $\begin{array}{c}\text { Total EAC } \\
\text { decrease }\end{array}$ & $\begin{array}{c}\text { Enzymatic } \\
\text { EAC balance }\end{array}$ & $\begin{array}{c}\text { Relative percent } \\
\text { of EAC }\end{array}$ \\
\hline \multirow{2}{*}{$\begin{array}{l}\text { Trypsin activity } \\
\left(\text { abs t }^{-1} \text { vol }^{-1}\right)\end{array}$} & A & $2.03-0.5$ & 2.87 & 2.51 & 1.04 & 77.7 \\
& B & $1.96-0.99$ & 3.69 & 3.52 & 1.14 & 100 \\
& C & $2.03-0.89$ & 3.68 & 3.32 & 1.10 & 100 \\
& D & $1.80-0.89$ & 3.24 & 2.87 & 1.12 & 88 \\
\hline \multirow{2}{*}{-amylase activity } & A & $0.029-0.021$ & $0.019^{\mathrm{x}}$ & $0.018^{\mathrm{x}}$ & 0.90 & 47 \\
& $\mathrm{~B}$ & $0.029-0.018$ & $0.037^{\mathrm{y}}$ & $0.037^{\mathrm{y}}$ & 1.01 & 53 \\
& $\mathrm{C}$ & $0.028-0.010$ & $0.045^{\mathrm{y}}$ & $0.049^{\mathrm{y}}$ & 1.08 & 71 \\
& $\mathrm{D}$ & $0.029-0.009$ & $0.068^{\mathrm{z}}$ & $0.070^{\mathrm{z}}$ & 1.02 & 100 \\
\hline
\end{tabular}

In aquaculture, shrimp are fed several times during the day to avoid starvation and maximize feed retention. Still, it was uncertain whether $P$. vannamei would take advantage of the feed supplied more frequently and at times other than after dusk. Previous results had been contradictory, but it was clear that feed intake and digestion by $P$. vannamei could be modulated by culture procedures for better management (Sainz-Hernández et al. 2005).

In the present study, shrimp that were offered feed several times throughout the day over a month did not ingest the feed similarly. The group with the most spaced feeding times, group A, ingested $90 \%$ of the feed during the day. This result agrees with other authors (Soares-Pontes et al. 2008), who mention that spaced feedings over the day may stimulate the animals to search for and ingest feed but does not necessarily stimulate more ingestion during a circadian period.

Fluctuations in enzymatic activity have been found in various studies, and trypsin activity usually fluctuates after ingestion (Hernandez-Cortes et al. 1999, Sainz-Hernández et al. 2004b). Those results almost fit the feeding regime in the present study, but this relation is not strict when fed once or twice during the day. No fluctuation in trypsin activity was seen at noon in the group fed four times, and there was a lower level of activity fluctuation in the group fed eight times per day; these small fluctuations did not have a strict relationship with ingestion. In contrast, $\alpha$-amylase activity appeared to increase after ingestion in all groups. It was not modified during the daytime in all regimes remaining constant around the highest level. Shrimp are nocturnally active, and although they were continuously fed during the day, most of their activity occurs during the night (Soares-Pontes et al. 2006, Santos et al. 2016). The natural behavior associated with the shrimp metabolism may be part of the enzyme activity, not demanding $\alpha$-amylase during the day because the shrimp is resting. Energy for shrimp activity mainly comes from carbohydrate catabolism, although they can use protein to obtain energy (Rosas et al. 2001, 2002). The results showed an apparent halt in the use of $\alpha$-amylase, which is responsible for the hydrolysis of $\alpha$-D $(1,4)$ glycoside linkages in polysaccharides starch, amylopectin, and glycogen, to produce energy (Van Wormhoudt \& Favrel 1988, Parameswaran et al. 2018). There is an interesting similarity in the expression of digestive enzymes $(\alpha-$ amylase, glucosidase, and total hexokinase activity) during the intermolt period, which could be explained if enzymes were produced expelled in a batch as a whole, including proteases. However, $\alpha$-amylases show remarkable resistance to that expression (Cuzon et al. 1980, Asaro et al. 2018).

More fluctuations in $\alpha$-amylase and trypsin activity were registered during the night hours when the feeding 
frequency increased. The maximum $\alpha$-amylase activity was approximately 0.03 units in all regimes, and the minimum activity was observed to decrease from 0.02 to 0.005 when the feed was offered more frequently, which suggests that more energy is required to translate more $\alpha$-amylase. In contrast, trypsin activity was shown to be more stable during different regimes. Feeding activity is related in different ways to the production and release of trypsin and $\alpha$-amylase enzymes. When there were more feeding events during the day, the total trypsin activity appeared to be relatively constant. Still, $\alpha$-amylase exhibited more than twice the overall $\alpha$ amylase activity when feeding more frequently. Protein synthesis is expensive, needing four to six molecules of ATP per peptide link (Racotta-Poulieff 2002). The $\alpha$ amylase gene encodes a mature protein of 495 amino acids in the DG, meaning that $2.475 \mathrm{kcal}$ are utilized to construct one molecule of $\alpha$-amylase. The results showed an elevation in the activity that was 2.6 times greater in shrimp fed eight times per day than in those fed only once, and 0.8 and 0.5 times greater when fed four and two times per day compared to being fed only once, respectively. If the increment in enzyme activity indicates an increase in enzyme translation, then the applied energy is in the same dimension, and it is not a negligible amount of energy. Sedgwick (1979), Robertson et al. (1993), and Tacon et al. (2002) mention that feeding frequency influenced the weight of shrimp, whereas other authors state that there is no influence (Velasco et al. 1999, Smith et al. 2002, Carvalho \& Nunes 2006). Thus, feeding frequency and amount may or may not influence biomass. Still, the energy levels resulting from the feeding frequency are essential for the performance of immunity and other energy-dependent shrimp metabolism functions, which help the shrimp survive against pathogens or environmental hardships and make aquaculture reliable (Pascual et al. 2004).

For P. vannamei, studied here, both trypsin and $\alpha-$ amylase activity showed a balance close to 1.0 , which means a rapid activity reconstitution required to continue their daily participation in catabolism health keeping.

Results from this study support the findings of Soares-Pontes et al. (2008). They found that feeding three times per day assumes lower labor costs, and it is a more efficient use of the feed. Peixoto et al. (2018) concluded that feeding three times a day provided the highest enzymatic activity and the best zootechnical performance of $P$. vannamei during the nursery phase in a biofloc system. We can also conclude that feeding two or four times per day utilizes a lower amount of energy than feeding more frequently, saving energy for other energy-dependent metabolic processes aside from the practical management of feeding less frequently.

\section{ACKNOWLEDGMENTS}

This work was supported by Instituto Politécnico Nacional (grant \#SIP20151139). Cinthya Guadalupe Juárez Acosta, received a CONACYT fellowship (grant \#395561). J.P. Apún-Molina, A. Santamaria-Miranda and J.C. Sainz-Hernandez received financial support from COFAA and E.D.I. scholarships from the Instituto Politécnico Nacional.

\section{REFERENCES}

Aguiñaga-Cruz, J.A., Sainz-Hernández, J.C., GarcíaRodríguez, L.D., García-Ulloa, M., García-Gutiérrez, C. \& Montoya-Mejía, M. 2019. Trypsin polymorphism and modulation in Penaeus vannamei (Boone, 1931): a review. Latin American Journal of Aquatic Research, 47: 723-732.

Aguiñaga-Cruz, J.A., Sainz-Hernández, J.C., GonzálezPrieto, J.M., Vargas-Albores, F., Sandoval-Castro, E., Rúbio-Gastelum, D., et al. 2017. Population structure of digestive trypsin phenotypes in hatcheries for pacific white shrimp and their frequencies during growth in commercial culture. North American Journal of Aquaculture, 79: 261-266. doi: 10.1080/ 15222055.2017.1317681

Asaro, A., Martos-Sitcha, J.A., Martínez-Rodríguez, G., Mancera, J.M. \& López Mañanes, A.A. 2018. In silico analysis and effects of environmental salinity in the expression and activity of digestive $\alpha$-amylase and trypsins from the euryhaline crab Neohelice granulata. Canadian Journal of Zoology, 96: 127-139.

Carvalho, E.A. \& Nunes, A.J. 2006. Effects of feeding frequency on feed leaching loss and grow-out patterns of the white shrimp Litopenaeus vannamei fed under a diurnal feeding regime in pond enclosures. Aquaculture, 252: 494-502.

Castro, P.F., Freitas Jr., A.C., Santana, W.M., Costa, H.M., Carvalho Jr., L.B. \& Bezerra, R.S. 2012. Comparative study of amylases from the midgut gland of three species of penaeid shrimp. Journal of Crustacean Biology, 32: 607-613.

Cuzon, G., Cahu, C., Aldrin, J., Messager, J., Stephan, G. \& Mevel, M. 1980. Starvation effect on metabolism of Penaeus japonicus. Journal of the World Aquaculture Society, 11: 410-423.

Díaz-Granda, E. 1997. Horarios de alimentación del camarón Penaeus schmitti en condiciones de cultivo semi-intensivo. Tesis de Maestría, Universidad de La Habana, La Habana. 
Erlanger, B.F., Kokowsky, N. \& Cohen, W. 1961. The preparation and properties of two new chromogenic substrates of trypsin. Archives of Biochemistry and Biophysics, 95: 271-278.

Gamboa-Delgado, J., Molina-Poveda, C. \& Cahu, C. 2003. Digestive enzyme activity and food ingesta in juvenile shrimp Litopenaeus vannamei (Boone, 1931) as a function of body weight. Aquaculture Research, 34: 1403-1411.

Gaxiola, G., Cuzon, G., García, T., Taboada, G., Brito, R., Chimal, M.E., et al. 2005. Factorial effects of salinity, dietary carbohydrate, and molt cycle on digestive carbohydrases and hexokinases in Litopenaeus vannamei (Boone, 1931). Comparative Biochemistry and Physiology - Part A: Molecular \& Integrative Physiology, 140: 29-39.

Harms, J., Anger, K., Klaus, S. \& Seeger, B. 1991. Nutritional effects on ingestion rate, digestive enzyme activity, growth, and biochemical composition of Hyas araneus L. (Decapoda: Majidae) larvae. Journal of Experimental Marine Biology and Ecology, 145: 233265.

Harris, R., Samain, J.-F., Moal, J., Martin-Jezequel, V. \& Poulet, S. 1986. Effects of algal diet on digestive enzyme activity in Calanus helgolandicus. Marine Biology, 90: 353-361.

Hernandez-Cortes, P., Rivera-Perez, C., Garcia-Carreño, F. \& Martinez-Alarcon, D. 2017. Proteinases during early development of the Pacific whiteleg shrimp Penaeus vannamei. Biological Bulletin, 232: 2-11.

Hernandez-Cortes, P., Quadros-Seiffert, W., Del Toro, M.N., Portillo, G., Colado, G. \& Garcia-Carreño, F. 1999. Rate of ingestion and proteolytic activity in digestive system of juvenile white shrimp, Penaeus vannamei, during continual feeding. Journal of Applied Aquaculture, 9: 35-45.

Hofer, R., Dalla-Via, G., Troppmair, J. \& Giussani, G. 1982. Differences in digestive enzymes between cyprinid and non-cyprinid fish. Memorie dell' Instituto Italiano di Idrobiologia, 40: 201-208.

Johnston, D. \& Freeman, J. 2005. Dietary preference and digestive enzyme activities as indicators of trophic resource utilization by six species of crab. Biological Bulletin, 208: 36-46.

Klein, B., Sellos, D. \& Van Wormhoudt, A. 1998. Genomic organization and polymorphism of a crustacean trypsin multi-gene family. Gene, 216: 123-129.

Klein, B., Le Moullac, G., Sellos, D. \& Van Wormhoudt, A. 1996. Molecular cloning and sequencing of trypsin cDNAs from Penaeus vannamei (Crustacea, Decapoda): use in assessing gene expression during the moult cycle. International Journal of Biochemistry \& Cell Biology, 28: 551-563.
Kumlu, M. \& Jones, D. 1995. The effect of live and artificial diets on growth, survival, and trypsin activity in larvae of Penaeus indicus. Journal of the World Aquaculture Society, 26: 406-415.

Le Moullac, G. \& Van Wormhoudt, A. 1994. Adaptation of digestive enzymes to dietary protein, carbohydrate and fibre levels, and influence of protein and carbohydrate quality in Penaeus vannamei larvae (Crustacea, Decapoda). Aquatic Living Resources, 7: 203-210.

Le Moullac, G., Klein, B., Sellos, D. \& Van Wormhoudt, A. 1997. Adaptation of trypsin, chymotrypsin, and $\alpha-$ amylase to casein level and protein source in Penaeus vannamei (Crustacea Decapoda). Journal of Experimental Marine Biology and Ecology, 208: 107-125.

Le Vay, L., Jones, D., Puello-Cruz, A., Sangha, R. \& Ngamphongsai, C. 2001. Digestion in relation to feeding strategies exhibited by crustacean larvae. Comparative Biochemistry and Physiology - Part A: Molecular \& Integrative Physiology, 128: 621-628.

Lovett, D.L. \& Felder, D.L. 1990. Ontogenetic change in digestive enzyme activity of larval and postlarval white shrimp Penaeus setiferus (Crustacea, Decapoda, Penaeidae). Biological Bulletin, 178: 144-159.

Lumasag, G.J., Quinitio, E.T., Aguilar, R.O., Baldevarona, R.B. \& Saclauso, C.A. 2007. Ontogeny of feeding apparatus and foregut of mud crab Scylla serrata Forsskål larvae. Aquaculture Research, 38: 1500-1511.

Parameswaran, B., Varjani, S. \& Raveendran, S. 2018. Green bio-processes: enzymes in industrial food processing. Springer, Berlin.

Pascual, C., Zenteno, E., Cuzon, G., Sánchez, A., Gaxiola, G., Taboada, G., et al. 2004. Litopenaeus vannamei juveniles energetic balance and immunological response to dietary protein. Aquaculture, 236: 431-450.

Peixoto, S., Silva, E., Costa, C., Nery, R., Rodrigues, F., Silva, J., et al. 2018. Effect of feeding frequency on growth and enzymatic activity of Litopenaeus vannamei during nursery phase in biofloc system. Aquaculture Nutrition, 24: 579-585.

Puello-Cruz, A., Sangha, R., Jones, D. \& Le Vay, L. 2002. Trypsin enzyme activity during larval development of Litopenaeus vannamei (Boone) fed on live feeds. Aquaculture Research, 33: 333-338.

Racotta-Poulieff, R. 2002. Metabolismo energetico en el humano: un enfoque cuantitativo. Instituto Politécnico Nacional, Ciudad de México.

Robertson, L., Lawrence, A.L. \& Castille, F.L. 1993. Effect of feeding frequency and feeding time on growth of Penaeus vannamei (Boone). Aquaculture Research, 24: 1-6. doi: 10.1111/j.1365-2109.1993. tb00823.x 
Rodríguez-Viera, L., Perera, E., Casuso, A., PerdomoMorales, R., Gutierrez, O., Scull, I., et al. 2014. A holistic view of dietary carbohydrate utilization in lobster: digestion, postprandial nutrient flux, and metabolism. Plos One, 9: e108875.

Rosas, C., Cuzon, G., Gaxiola, G., Pascual, C., Taboada, G., Arena, L. \& Van Wormhoudt, A. 2002. An energetic and conceptual model of the physiological role of dietary carbohydrates and salinity on Litopenaeus vannamei juveniles. Journal of Experimental Marine Biology and Ecology, 268: 47-67.

Rosas, C., Cuzon, G., Gaxiola, G., Le Priol, Y., Pascual, C., Rossignol, J., et al. 2001. Metabolism and growth of juveniles of Litopenaeus vannamei: effect of salinity and dietary carbohydrate levels. Journal of Experimental Marine Biology and Ecology, 259: 1-22.

Sainz-Hernández, J.C., García-Carreño, F.L. \& HernándezCortés, P. 2004a. Penaeus vannamei isotrypsins: purification and characterization. Comparative Biochemistry and Physiology - Part B: Biochemistry and Molecular Biology, 138: 155-162. doi: 10.1016/ j.cbpc.2004.03.002

Sainz-Hernández, J.C., García-Carreño, F.L., CórdovaMurueta, J.H. \& Cruz-Hernández, P. 2005. Whiteleg shrimp (Litopenaeus vannamei, Boone, 1931) isotrypsins: their genotype and modulation. Journal of Experimental Marine Biology and Ecology, 326: 105113. doi: 10.1016/j.jembe.2005.05.021

Sainz-Hernández, J.C., García-Carreño, F., SierraBeltrán, A. \& Hernández-Cortés, P. 2004b. Trypsin synthesis and storage as zymogen in the midgut gland of the shrimp Litopenaeus vannamei. Journal of Crustacean Biology, 24: 266-273.

Santos, A.D.A., López-Olmeda, J.F., Sánchez-Vázquez, F.J. \& Fortes-Silva, R. 2016. Synchronization to light and mealtime of the circadian rhythms of self-feeding behavior and locomotor activity of white shrimps (Litopenaeus vannamei). Comparative Biochemistry and Physiology - Part A: Molecular \& Integrative Physiology, 199: 54-61.

Sedgwick, R. 1979. Effect of ration size and feeding frequency on the growth and food conversion of juvenile Penaeus merguiensis de Man. Aquaculture, 16: 279-298.

Received: 19 March 2020; Accepted: 17 December 2020
Sellos, D. \& Van Wormhoudt, A. 1992. Molecular cloning of a cDNA that encodes a serine protease with chymotryptic and collagenolytic activities in the hepatopancreas of the shrimp Penaeus vannamei (Crustacea, Decapoda). FEBS Letters, 309: 219-224.

Simon, C.J. 2009. Digestive enzyme response to natural and formulated diets in cultured juvenile spiny lobster, Jasus edwardsii. Aquaculture, 294: 271-281.

Smith, D., Burford, M., Tabrett, S., Irvin, S. \& Ward, L. 2002. The effect of feeding frequency on water quality and growth of the black tiger shrimp (Penaeus monodon). Aquaculture, 207: 125-136.

Soares-Pontes, C., Pereira de Lima, P. \& Arruda, M.de F. 2008. Feeding responses of juvenile shrimp Litopenaeus vannamei (Boone) fed at different frequencies under laboratory conditions. Aquaculture Research, 39: 1416-1422.

Soares-Pontes, C., Arruda, M. de F., De Lara-Menezes, A.A. \& Pereira de Lima, P. 2006. Daily activity pattern of the marine shrimp Litopenaeus vannamei (Boone 1931) juveniles under laboratory conditions. Aquaculture Research, 37: 1001-1006.

Tacon, A., Cody, J., Conquest, L., Divakaran, S., Forster, I. \& Decamp, O. 2002. Effect of culture system on the nutrition and growth performance of Pacific white shrimp Litopenaeus vannamei (Boone) fed different diets. Aquaculture Nutrition, 8: 121-137.

Van Wormhoudt, A. \& Favrel, P. 1988. Electrophoretic characterization of Palaemon elegans (Crustacea, Decapoda) $\alpha$ amylase system: study of amylase polymorphism during the intermolt cycle. Comparative Biochemistry and Physiology - Part B: Comparative Biochemistry, 89: 201-207.

Velasco, M., Lawrence, A.L. \& Castille, F.L. 1999. Effect of variations in daily feeding frequency and ration size on growth of shrimp, Litopenaeus vannamei (Boone), in zero-water exchange culture tanks. Aquaculture, 179: 141-148.

Ziaei-Nejad, S., Habibi-Rezaei, M.H., Takami, G.A., Lovett, D.L., Mirvaghefi, A.R. \& Shakouri, M. 2006. The effect of Bacillus spp. bacteria used as probiotics on digestive enzyme activity, survival and growth in the Indian white shrimp Fenneropenaeus indicus. Aquaculture, 252: 516-524. 